\title{
Infectious salmon anaemia (ISA) risk factors in sea-cultured Atlantic salmon Salmo salar
}

\author{
J. Jarp ${ }^{1, *}$, E. Karlsen ${ }^{2}$ \\ ${ }^{1}$ National Veterinary Institute, POB 8156 Dep., N-0033 Oslo 1, Norway \\ ${ }^{2}$ Regional Veterinary Office for Troms and Finnmark, POB 652, N-9401 Harstad, Norway
}

\begin{abstract}
A matched case-control study of infectious salmon anaemia (ISA) risk factors in Norwegian salmonid sea sites was performed in 1993. The distribution of potential exposure factors associated with the site management and location was compared in 2 paired groups of sea sites, one group comprising 37 ISA-positive sites and the other 37 ISA-negative sites. The risk of ISA was found to be significantly associated with the location of the site. Location within $5 \mathrm{~km}$ from a salmonid slaughterhouse gave an ISA odds ratio of 13.0 compared to location further away. The risk of infection increased by 8.0 if the site was situated closer than $5 \mathrm{~km}$ to another ISA-positive site as compared to the risk when the site was more than $5 \mathrm{~km}$ away. Disinfecting the waste water from the slaughtering and processing plants seemed to prevent transmission of ISA. The density of fish markets for sea-caught fish was higher in the vicinity of cases than of controls. The risk of ISA was associated with the number of hatcheries delivering smolt to the sea sites, and the risk increased if the hatcheries were located outside the site's home county. The overall results from the present study indicate that ISA is mainly transmitted from infected salmonid sources to clean sites through sea water. Further disease control measures should concentrate on minimising the risk of transmission through sea water by shortening the time period between the diagnosis of ISA and the elimination of positive sites, and should work towards the establishment of $5 \mathrm{~km}$ as a minimum distance between sea sites. In addition, decontamination systems must be systematically introduced into the fish processing industry. The implementation of good sanitary practices by fish farmers may also reduce the risk of ISA.
\end{abstract}

KEY WORDS: Epidemiology Disease - Risk factors - Infectious salmon anaemia

\section{INTRODUCTION}

The first case of infectious salmon anaemia (ISA) was diagnosed in Atlantic salmon parr Salmo salar L. in a hatchery on the west coast of Norway in 1984 (Thorud 1991). In this outbreak, which lasted for several months, fish mortality in the hatchery reached approximately $80 \%$. The affected parr were kept in smolt tanks where the fresh water was mixed with raw sea water, but afterwards no naturally occurring cases were registered in fry or smolt prior to seawater transfer until 1995. The most serious problems associated with the diagnosis of ISA in the farmed population of Atlantic salmon were registered in sea farms. The mor-

•E-mall: jorun.jarp@vetinst.no tality associated with ISA in sea farms varies considerably from insignificant to moderate.

In 1995 the causal virus of ISA was isolated from cultured cells in the laboratory (Dannevig et al. 1995). Prior to this confirmation of the viral aetiology, the results from several studies indicated that the disease was transmissible (Thorud 1991, Dannevig et al. 1994, Vågsholm et al. 1994). The virus is not yet fully classified, although it seems to be an orthomyxo-like RNAvirus (S. Mjaaland pers. comm.).

Since the first appearance of ISA in 1984, the disease has been compulsorily notifiable in Norway. During the period from 1988 to 1990, the annual number of new fish farming sites with ISA increased and reached a maximum of 101 in 1990. Later the annual number of new cases decreased to a minimum of 1 in 1994, but 
still the occurrence of 2 and 5 new cases in 1995 and 1996, respectively, shows that the disease has not been eradicated (Bakken 1995). ISA has been registered only in Norway. Because the export of fish may be banned due to the fear of introduction of ISA to other countries, it is of major interest for Norway to eradicate the disease from farmed fish.

Since 1990, the Norwegian Ministry of Agriculture has issued several aquaculture regulations aimed at reducing the transmission of fish infections. These include compulsory veterinary health control in smolt plants, a compulsory health certification for the sale of fish, and regulations concerning the transport of live fish. The authorities have also required that waste water from the salmonid processing plants be disinfected, but such systems have not been installed all plants. The regulations issued are based on general experience concerning the transmission of infectious agents and are supported by previous epidemiological studies of infectious diseases in the farmed fish population (Jarp et al. 1993, Vågsholm et al. 1994) In addition to the development of more efficient diagnostic tests, it seems that a better knowledge of the epidemiology of ISA must be gained if total eradication of the disease is to be achieved.

The aim of the present study was to analyse the potential association between factors such as site location, site management, environmental factors, and the risk of introducing ISA into an Atlantic salmon sea site.

\section{MATERIALS AND METHODS}

Design and sites. A pair-matched case-control study (Schlesselman 1982) was designed with the salmonid sea site as the unit of concern. Sites located along the coast of Norway from Hordaland in the south to Troms in the north were eligible for the study.
A case farm was defined as a farm from which ISA had been notified by the Ministry of Agriculture due to its confirmed occurrence in Atlantic salmon during the period from 1 January 1992 to 1 September 1993. In all case farms, the diagnosis of ISA was verified by pathological and haematological investigations performed at one of the State Veterinary Laboratories.

A control farm was defined as a sea site which was located within the same veterinary district and which had the same year-class of Atlantic salmon during the same time period as the matched case farm, but in which ISA was neither diagnosed nor suspected.

Questionnaire. A standardised questionnaire was mailed to the Regional Veterinary Officer in the area where the selected sites were located. In case farms, information was requested as to when ISA was diagnosed, when the site was notified, in which year-class the disease primarily occurred, and the date for depopulation of the site or the date of planned slaughtering. For all sites, information was recorded concerning the type of site, management, and location relative to slaughter or processing sites and other farms (Tables 1 $\& 2$ ). In addition, the hygienic standard and operational practices of slaughterhouses and processing plants in the neighbourhood of the site were registered (Table 3). In processing plants no primary slaughtering occurs, but carcasses or filets are brought in for further processing from other slaughterhouses.

Statistical analysis. Site was used as the statistical unit in the analysis, with the presence/absence of ISA as the dichotomous dependent variable. The analysis was stratified, with 'pair', the matching factor, as the stratifying variable. The association between the various independent variables in the study and the dependent variable was investigated in various statistical analyses using the SAS-PC System $B$ Version 6.08 or 6.10 for Windows (SAS Institute Inc., Cary, NC, USA, 1989). The relationships between the status of ISA and

Table 1. Description and mean values of potential non-categoric risk factors of ISA in a matched study of 37 cases and 37 controls

\begin{tabular}{|c|c|c|}
\hline Varlable description & Cases $(\mathrm{N})$ & Controls $(\mathrm{N})$ \\
\hline Distance to the nearest slaughterhouse $(\mathrm{km})$ & 6.1 & $8.8^{\mathrm{d}}$ \\
\hline Distance to the nearest ISA-positive salmonid sea site $(\mathrm{km})$ & 45.0 & 43.8 \\
\hline Distance to the nearest salmonid sea site $(\mathrm{km})$ & 4.8 & 5.2 \\
\hline Number of salmonid slaughterhouses within $5 \mathrm{~km}$ & 0.84 & $0.40^{\circ}$ \\
\hline Number of processing plants wathin $5 \mathrm{~km}$ & 0.08 & 0.03 \\
\hline Number of fish markets for sea-caught fish within $5 \mathrm{~km}$ & 0.94 & $0.64^{\mathrm{a}}$ \\
\hline Annual volume of salmonids slaughtered in the nearest slaughterhouses $\left(\mathrm{m}^{3}\right)$ & 1176 & 1484 \\
\hline Licensed production volume at sea site $\left(\mathrm{m}^{3}\right)$ & 13918 & 13189 \\
\hline Number of sea-transferred smolt of the year-class in question & 149972 & 139279 \\
\hline Depth of pens at sea site $(\mathrm{m})$ & 8.8 & 8.5 \\
\hline Depth to sea bottom at site $(m)$ & 35.9 & 38.3 \\
\hline
\end{tabular}


Table 2. Description, distribution and the unadjusted matched odds ratio [90\% confidence intervals (Cl)] for potential categoric risk factors for ISA in a study of 37 cases and 37 controls. ND: not determined

\begin{tabular}{|c|c|c|c|c|}
\hline Variable description & Categonsation level & $\begin{array}{c}\text { Cases } \\
(N)\end{array}$ & $\begin{array}{c}\text { Controls } \\
(\mathrm{N})\end{array}$ & $\begin{array}{l}\text { Unadjusted matched } \\
\text { odds ratio }(90 \% \mathrm{Cl})\end{array}$ \\
\hline Dead fish removal during summer & $\begin{array}{l}\text { Daly } \\
\text { Less frequently }\end{array}$ & $\begin{array}{l}18 \\
19\end{array}$ & $\begin{array}{l}24 \\
13\end{array}$ & $3.0(1.0-9.0)$ \\
\hline Dead fish removal during winter & $\begin{array}{l}\text { Dally } \\
\text { Less frequently }\end{array}$ & $\begin{array}{l}11 \\
24\end{array}$ & $\begin{array}{l}13 \\
24\end{array}$ & $\begin{array}{c}1 \\
1.0(0.4-2.4)\end{array}$ \\
\hline Method used for treatment of dead fish & $\begin{array}{l}\text { Ground infiltration } \\
\text { Acid treatment } \\
\text { Freezing }\end{array}$ & $\begin{array}{r}34 \\
1 \\
2\end{array}$ & $\begin{array}{r}34 \\
2 \\
1\end{array}$ & $\mathrm{ND}$ \\
\hline Sharing of personnel with other sites & $\begin{array}{l}\text { No } \\
\text { Yes }\end{array}$ & $\begin{array}{r}34 \\
3\end{array}$ & $\begin{array}{r}31 \\
5\end{array}$ & $\begin{array}{c}1 \\
0.8(0.3-1.8)\end{array}$ \\
\hline Sharing of equipment with other sites & $\begin{array}{l}\text { No } \\
\text { Yes }\end{array}$ & $\begin{array}{r}33 \\
4\end{array}$ & $\begin{array}{r}32 \\
4\end{array}$ & $\begin{array}{c}1 \\
0.6(0.2-2.0)\end{array}$ \\
\hline Number of freshwater hatcheries delivering the smolt & $\begin{array}{l}\text { One } \\
\text { Several }\end{array}$ & $\begin{array}{l}13 \\
24\end{array}$ & $\begin{array}{l}21 \\
16\end{array}$ & $\frac{1}{2.6(1.1-6.2)^{\mathrm{b}}}$ \\
\hline Purchase of smolt from outside home county & $\begin{array}{l}\text { No } \\
\text { Yes }\end{array}$ & $\begin{array}{l}25 \\
12\end{array}$ & $\begin{array}{r}32 \\
5\end{array}$ & $3.3(1.3-9.8)^{b}$ \\
\hline Net pen arrangement & $\begin{array}{l}\text { Chains } \\
\text { Clusters }\end{array}$ & $\begin{array}{r}3 \\
34\end{array}$ & $\begin{array}{r}8 \\
30\end{array}$ & $3.0(0.8-11.5)$ \\
\hline Location of sea site according to the LENKA system & $\begin{array}{l}\mathrm{A} \\
\mathrm{B} \text { or } \mathrm{C}\end{array}$ & $\begin{array}{l}17 \\
20\end{array}$ & $\begin{array}{l}19 \\
17\end{array}$ & $\frac{1}{1.4(0.5-3.7)}$ \\
\hline
\end{tabular}

the noncategoric independent variables were screened in a nonparametric signed rank test. Before the association between the ISA status and the various noncategorical independent variables was tested further, the variables were categorised. A univariate conditional logistic regression analysis was used for categorical variables with more than 2 levels. The McNemar chisquare was calculated using Epi Info Version 5 (Dean et al, 1990) to evaluate the significance level of dichotomous independent variables.

The possible categorisation level for the potential risk factors associated with location in relation to the nearest other sites, another ISA-positive site, and slaughterhouses was analysed unstratified. For each $\mathrm{km}$ distance from a potential risk site, the proportions of ISA-positive sites inside this $\mathrm{km}$ limit and that of ISA-negative sites outside were calculated and plotted against each other. The categorisation level used in the further analysis was chosen as the $\mathrm{km}$-value which was associated with the largest change in the proportion of ISA-negative sites outside the zone (Altman 1991).

For the variables associated with the number of slaughterhouses, the chosen reference level was no slaughterhouse within a distance of $5 \mathrm{~km}$ from the site in question. This level was compared to 2 other levels: at least 1 slaughterhouse with an approved system for disinfection of the waste water, and at least 1 slaughterhouse without such a system.
After univariate analysis, all variables which were significantly associated with the dependent variable at a significance level at or below 0.10 were tested in a multivariate conditional logistic regression model. In addition, the distance of the site to the nearest ISA-positive site was analysed. Potential confounding between the various independent variables was analysed by comparing the crude odds ratios with the odds ratios adjusted for the other variables included in a multivariate model.

\section{RESULTS}

\section{Description of cases}

The 37 cases were located in the coastal counties of Hordaland (14), Sogn og Fjordane (5), Møre and Romsdal (9), Sør Trondelag (2), Nord Trøndelag (1), Nordland (5), and Troms (1). The seasonal distribution of the occurrence of the disease in the 37 case sites was as follows: 8 in the first quarter of the year, 18 in the second, 5 in the third, and 6 in the fourth.

The mean time period from transfer of the salmon to a sea site until the occurrence of ISA was $12.2 \mathrm{mo}$. In one sea site, the disease occurred 1 mo after transfer to a sea site, whereas the maximum lag period from transfer to manifestation of disease was 30 mo (Fig. 1). The average time lapse between the occur- 
Table 3. Description, distribution and the unadjusted matched odds ratio [90\% confidence intervals [CI)] for ISA of potential risk factors associated with location and hygienic standard of slaughterhouses and processing plants near the 37 cases and 37 controls. ND: not determined

\begin{tabular}{|c|c|c|c|c|}
\hline Variable description & Categorisation level & $\begin{array}{l}\text { Cases } \\
(\mathrm{N})\end{array}$ & $\begin{array}{l}\text { Controls } \\
\text { (N) }\end{array}$ & $\begin{array}{l}\text { Unadjusted matched } \\
\text { odds ratio }(90 \% \mathrm{Cl})\end{array}$ \\
\hline \multirow{3}{*}{$\begin{array}{l}\text { Location and hygienic standard of } \\
\text { nearest slaughterhouse }\end{array}$} & None within $5 \mathrm{~km}$ & 15 & 24 & $1^{a, b}$ \\
\hline & $\begin{array}{l}\text { At least } 1 \text { plant, and all with } \\
\text { an approved system for } \\
\text { disinfection of waste water }\end{array}$ & 8 & 10 & $1.6(0.5-4.6)$ \\
\hline & $\begin{array}{l}\text { At least } 1 \text { plant, but none } \\
\text { with disinfection }\end{array}$ & 14 & 3 & $14.6(2.4-87.6)$ \\
\hline \multirow{4}{*}{$\begin{array}{l}\text { Method used for disinfection of waste water } \\
\text { in the nearest slaughterhouse }\end{array}$} & Heat & 1 & 1 & $\mathrm{ND}$ \\
\hline & Acid & 10 & 5 & \\
\hline & Sodium hydroxide & 10 & 6 & \\
\hline & Infiltration into the ground & 1 & 0 & \\
\hline \multirow{2}{*}{$\begin{array}{l}\text { Method used for transport of live fish to the } \\
\text { nearest slaughterhouse }\end{array}$} & Boat & 12 & 6 & ND \\
\hline & Transport pen & 10 & 6 & \\
\hline \multirow{3}{*}{$\begin{array}{l}\text { Location and hygienic standard of the nearest } \\
\text { salmonict processing plant }\end{array}$} & None within $5 \mathrm{~km}$ & 26 & 32 & 1 \\
\hline & $\begin{array}{l}\text { At least } 1 \text { plant, and all with } \\
\text { an approved system for } \\
\text { disinfection of waste water }\end{array}$ & 4 & 2 & $4.5(0.6-34.8)$ \\
\hline & $\begin{array}{l}\text { At least } 1 \text { plant, but none } \\
\text { with disinfection }\end{array}$ & 7 & 3 & $3.8(0.9-16.0)$ \\
\hline \multirow[t]{2}{*}{ Use of frozen salmonid carcasses in processing } & No & 11 & 4 & ND \\
\hline & Yes & 2 & 1. & \\
\hline \multirow{3}{*}{$\begin{array}{l}\text { Location of the nearest salmonid processing } \\
\text { plant in which frozen carcasses are used }\end{array}$} & None within $5 \mathrm{~km}$ & 27 & 32 & $1^{b}$ \\
\hline & $\begin{array}{l}\text { At least } 1 \text { plant, and all with } \\
\text { an approved disinfection } \\
\text { system for waste water }\end{array}$ & 3 & 2 & $1.7(0.4-7.8)$ \\
\hline & $\begin{array}{l}\text { At least } 1 \text { plant, but none with } \\
\text { disinfection }\end{array}$ & 7 & 3 & $8.7(1.3-58.8)$ \\
\hline \multirow{2}{*}{$\begin{array}{l}\text { Common ownership between sea site and } \\
\text { nearest slaughterhouse }\end{array}$} & No & 11 & 6 & ND \\
\hline & Yes & 9 & 8 & \\
\hline
\end{tabular}

rence of the disease in the case sites and the decision to slaughter or the actual slaughter of all fish at the location was 3.7 mo $195 \%$ confidence intervals (CI): 2.9 to 4.5$]$

\section{Location of site}

Some variables associated with the location of the site were shown to be significantly related to the risk of ISA. For cases and controls, the mean distance to the nearest slaughterhouse was 6.1 and $8.8 \mathrm{~km}$, respectively (Table 1). The mean distance from the nearest ISA-positive site to the case sites $(45.0 \mathrm{~km})$ was nearly the same as the mean distance to the ISA-negative controls $(43.8 \mathrm{~km})$, and the result from the paired analysis showed a non-significant difference between cases and controls ( $\mathrm{p}$-value: 0.31). However, further analysis showed that the distribution of the paired difference was skewed. Fig. 2 shows the proportion of ISA-positive sites inside, and the proportion of ISAnegative sites outside, the various zones from the closest ISA-positive site (Fig. 2A) and the nearest slaughterhouse (Fig. 2B). The proportion of ISA-positive sites within a $5 \mathrm{~km}$ radius from either an ISA-positive site or a slaughterhouse was 0.29 and 0.53 , respectively. Inside the same area, the proportion of ISA-negative sites was 0.05 and 0.19 , respectively. In both plots the upper lines, associated with the proportion of negative sites outside the specific zones, dropped more steeply when the zone was extended from 5 to $6 \mathrm{~km}$ from the risk units concerned (Fig $2 \mathrm{~A}$ or B), indicating that the proportion of ISA-negative sites located outside the zone fell markedly when the zone boundary was extended from 5 to $6 \mathrm{~km}$ from such a unit. Based on these results, a cut-off value for a distance of less than 


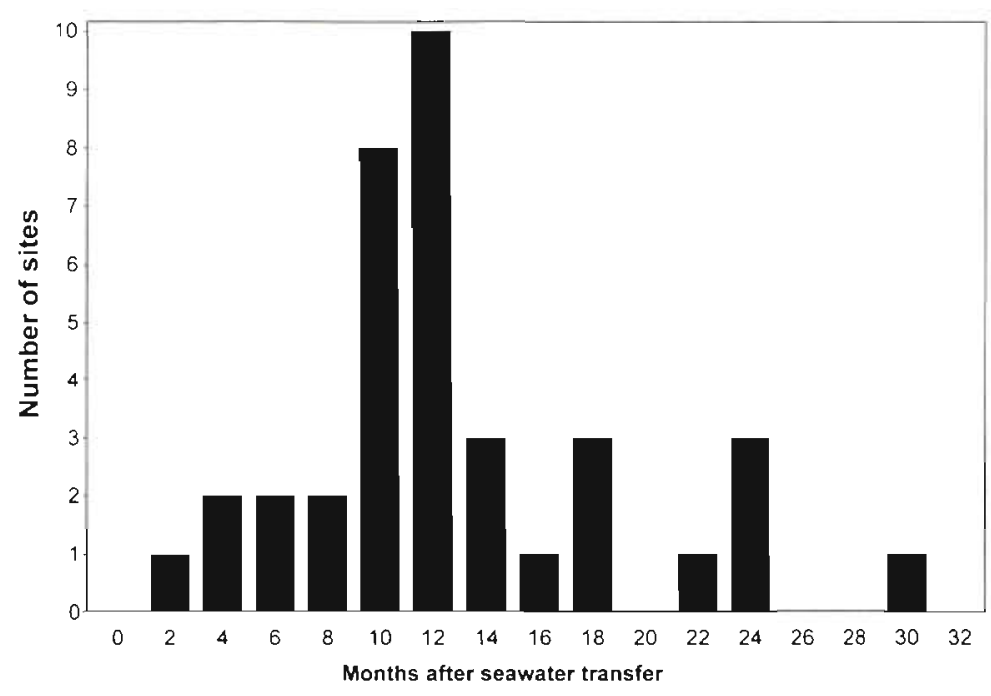

Fig. 1. Distribution of the relative time periods between transfer to a sea site and occurrence of ISA at 37 sea cage sites

or equal to $5 \mathrm{~km}$ was chosen in all further analyses of the risk associated with location.

The odds ratio for infection was 8.0 (90\% CI: 1.4 to 45.8) when the site was located closer than $5 \mathrm{~km}$ to another ISA-positive site as compared to sites located more than $5 \mathrm{~km}$ from a notified site.

If the sea site was located less than $5 \mathrm{~km}$ from a slaughterhouse, the crude odds of ISA-infection significantly increased by 13.0 (90\% CI: 2.4 to 71.7 ) as compared to the risk if no slaughterhouse was closer than $5 \mathrm{~km}$. When compared to the reference group of sites located further than $5 \mathrm{~km}$ from any slaughterhouse, a distance of less than $5 \mathrm{~km}$ to a slaughterhouse without an approved system for disinfecting waste was associated with increased odds of infection of 14.6 (90\% CI: 2.4 to 87.6$)$, whereas location near a slaughterhouse with a waste water disinfecting system increased the risk by only 1.6 (90\% CI: 0.5 to 4.6) (Table 3). Waste water disinfecting systems included ground infiltration $(6 \%)$, treatment with formic acid (44\%), sodium hydroxide $(47 \%)$, or heat $(3 \%)$. However, the disinfecting method used for the waste water had no influence on the risk of ISA infection.

The location of a sea site close to a processing plant where the waste water arising from the processing of fish was not disinfected also increased the risk of ISA at these sites. If frozen carcasses were used in a processing plant within $5 \mathrm{~km}$ of a sea site, and the waste water arising from the thawing of such carcasses was not disinfected, the risk of ISA at the sea site was $8.7(90 \% \mathrm{Cl}: 1.3$ to 58.8$)$ times greater than at a location further than $5 \mathrm{~km}$ away from any processing plant using frozen salmonid fish carcasses. The corresponding increase in risk at the sites within $5 \mathrm{~km}$ of plants which disinfected the thawing water was 1.7 (90\% CI: 0.4 to 7.8 ) (Table 3 ).

The number of slaughterhouses and the number of markets for sea-caught fish were both higher around the cases than around the controls but the differences were not significant (Table 1). The mean size of the nearest slaughterhouse, as measured by the annual volume of fish slaughtered, was nearly the same for cases and controls
Fig. 2. Proportion of ISApositive sites located inside (口) and ISA-negative sites located outside (a) the various zones from 1 to $9 \mathrm{~km}$ from (A) the closest ISA-positive site or, (B) the nearest slaughterhouse

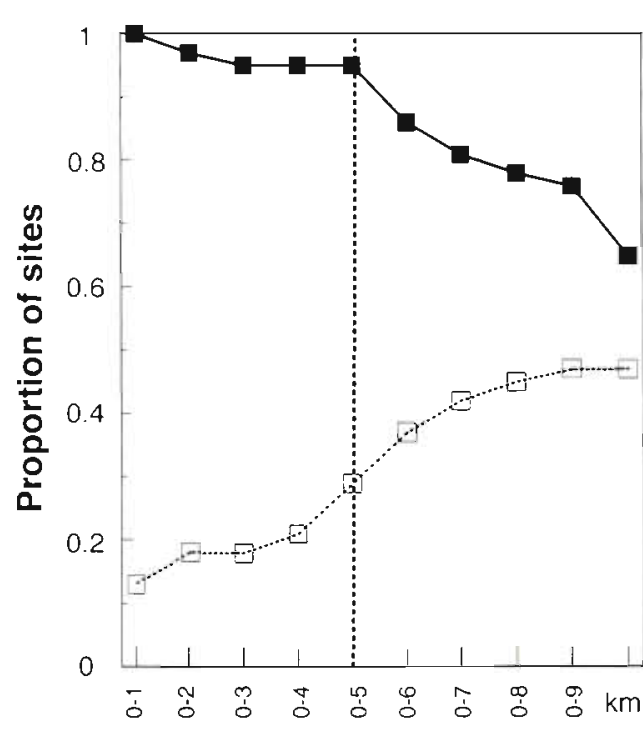

A (ISA-positive site)

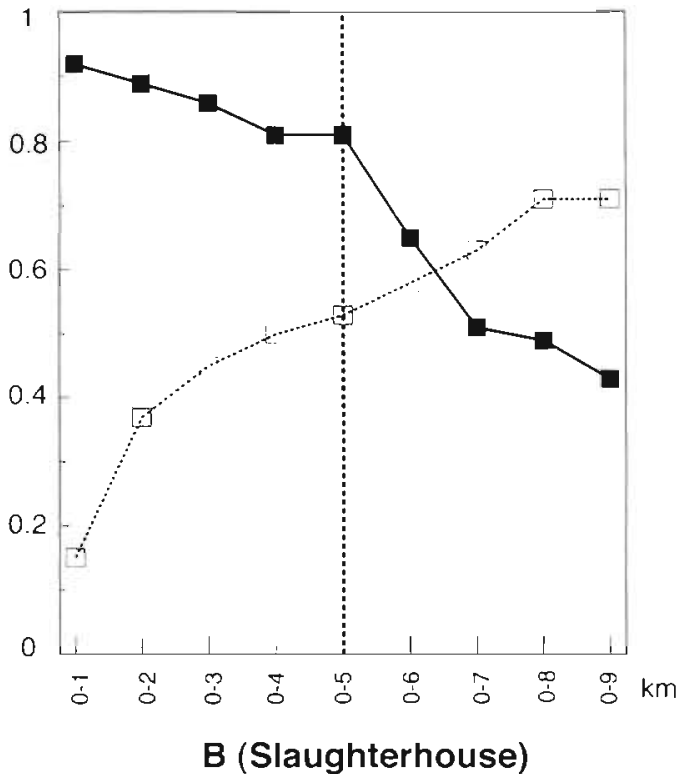


Neither the distance from the site to another salmonid sea site, the density in the area of other salmonid sites, the location according to the LENKA system (Anonymous 1990), nor the depth at the site were significantly related to the risk of ISA.

\section{Site management factors}

The risk of introducing ISA into a sea site was 2.6 (90\% CI: 1.1 to 6.2 ) times greater if the number of freshwater hatcheries delivering smolt increased from one to more than one (Table 2). If some or all of the smolts were purchased from a freshwater hatchery outside the sea site home county, the risk of introducing ISA increased 3.3-fold (90\% CI: 1.3 to 9.8 ) as compared to when smolt was purchased only from hatcheries in the home county. Farmers who purchased smolt from several hatcheries were also more likely to purchase smolt from a hatchery in another county.

The risk of ISA was $3.0(90 \% \mathrm{Cl}: 1.0$ to 9.0$)$ times greater in sites where the dead fish were not removed daily during the summer as compared to sites where the dead fish were removed every day (Table 2). However, during the winter the frequency of removal of dead fish did not seem to be related to the risk of ISA. In sites with pens arranged in a concentrated cluster arrangement, the risk of contracting ISA was $3.0190 \%$ CI: 0.8 to 11.5) greater as compared to sites with the net pens arranged in a longitudinal chain system.

\section{Multivariate analysis}

All the tested extensions of the univariate model were found not significant at a $5 \%$ level. The bestfitting multivariate model consisted of 2 terms: location closer than $5 \mathrm{~km}$ to or further than $5 \mathrm{~km}$ from a slaughterhouse and another ISA-positive sea site. The adjusted matched odds ratio for location nearer than $5 \mathrm{~km}$ from a slaughterhouse was 9.5 (90\% CJ: 1.7 to 54.1) (Wald's p-value: <0.05), and for location nearer than $5 \mathrm{~km}$ from another ISA-positive sea site the adjusted odds changed to 3.7 (90\% Cl: 0.6 to 23.2) (Wald's p-value: $<0.25$ )

\section{DISCUSSION}

The results from this study indicate that sea water has constituted a major route for the transmission of ISA to salmonid net pen sites. Proximity of the salmonid sea sites to the slaughterhouses and processing plants and to ISA-positive sites seemed crucial for the spread of the infection. It was shown that very few of the ISA-negative sites were located close to a salmonid slaughterhouse or an ISA-positive site. In an earlier study of the epidemiology of ISA, location of the sea sites in relation to other ISA-positive sites was also found to be a significant risk factor (Vagsholm et al. 1994), although the actual distances between the various units were not registered. In light of the parallel cut-off values associated with distance from a slaughterhouse and distance to an ISA-positive site found in the present study, a minimum distance of $5 \mathrm{~km}$ between aquaculture units is recommended if the risk of passive transmission of the ISA-agent through sea water is to be reduced. It has also been shown that the risk of infection with Aeromonas salmonicida subsp. salmonicida in Norwegian freshwater hatcheries was associated with the density of furunculosis-positive sea farms around the hatcheries (Jarp et al. 1993). The results from all these studies show that in order to reduce possible transmission of infections it is important to focus on the location of the various components of the salmonid farming industry. In order to gain further understanding of the importance of the location of sea sites in relation to the passive spread of infectious agents through sea water, oceanographic studies should be conducted.

The results from this study strongly support the existing requirement of the Norwegian veterinary authorities that disinfecting systems for the effluents from salmonid slaughterhouses and processing plants be installed (Torgersen \& Håstein 1995). All ISA-positive fish have to be slaughtered in slaughterhouses following sanitary procedures and standards approved by these veterinary authorities. Since the risk of ISA increased significantly only when the nearest slaughter plant had no disinfecting system for waste water, some ISA-infected fish most certainly have been slaughtered in non-approved plants.

The risk of ISA was found to be considerably greater when the site was located close to a processing plant in which the waste water arising from the thawing of frozen fish was not disinfected. Such thawing is performed by bathing the fish for several hours in large tanks of ice-cold water. Since large volumes of water are used, it has been argued by the industry that disinfecting the thawing water is both difficult and expensive

The fact that no difference in risk could be found between the various disinfecting methods used for the waste water agrees well with findings from controlled inactivation trials with ISA-infective tissue homogenate from infected fish. Torgersen et al. (1993) have shown that infectivity is quickly reduced by treatment with heat, sodjum hydrochloride, ozone or treatment with ultraviolet radiation, whereas formic acid or sodium hydroxide requires a long contact time to be effective 
The latency period for ISA in Atlantic salmon in sea water is not known. In controlled transmission trials of ISA, the first mortality is usually observed 1 to $3 \mathrm{wk}$ after primary inoculation. (Thorud 1991, Dannevig et al. 1994). In the case sites, ISA was diagnosed in the primarily affected fish about 1 yr after sea transfer, which also strongly supports the hypothesis that most of the affected fish are infected during the seawater phase.

It was estimated that almost 4 mo elapsed between verification of the ISA diagnosis and the slaughter of all fish at a site. In order to reduce the likelihood of the spread of ISA from a site where it has been diagnosed, it is crucial that a diagnosis is made as soon as possible after the disease has appeared and that the site is then completely depopulated without delay.

Our results support the findings of Vagsholm et al. (1994) that the purchase of smolts from several freshwater hatcheries is an important risk factor for the introduction of ISA into sea sites. Such mixing of smolts of different origins in the same site is very common in sea farming, although it has been shown that this practice is associated with an increased risk of other fish diseases. Jarp et al. (1995) showed that the risk of infectious pancreatic necrosis in post-smolt during the first 4 mo after sea transfer increased significantly when the number of smolt suppliers increased. Fish farmers should take notice of these findings, which are also supported by results from epidemiological studies of infectious diseases in other animals (Webster et al. 1985, Pritchard et al. 1989, Thomsen et al. 1992).

The present study revealed that the smolts in ISApositive sites were more often purchased from a smolt producer outside the site's home county than was the case for control sites. Such purchase from distant suppliers was also coupled with purchase from several producers. Since naturally occurring cases of ISA have been diagnosed most frequently in fish after seawater transfer, it is more probable that the increased risk associated with the purchase of smolt may be explained by the spread of ISA during transportation, for example due to the transport vehicles used, than by a possible undiagnosed latent ISA in the smolt. Coincident with Vågsholm et al. (1994), we found no significant increased risk of ISA related to a high density of sea farms around the seawater sites. This supports the belief that latent infection in farmed salmonids is of minor importance.

The present case-control study provided significant results, despite the fact that the sample size was low. As a questionnaire was used for data collection, the quality of the various exposure data can be questioned. However, because of the low probability of latent undiagnosed ISA and the exclusion of non-verified cases from the study, the chance of misclassification bias in the study is considered to be slight.

The overall results from the present study indicate that ISA is mainly transmitted from infected salmonid sources to clean sites through sea water Disease control measures should concentrate on minimising the risk of transmission through sea water by shortening the time period between diagnosis of ISA and elimination of positive sites, and work towards the establishment of $5 \mathrm{~km}$ as a minimum distance between sea sites. The implementation of good sanitary practices by fish farmers may also reduce the risk of ISA.

Acknowledgements. The authors acknowledge the help of various members of the Norwegian veterinary service with the collection of the data

\section{LITERATURE CITED}

Altman DG (1991) Some common problems in medical research. In: Altman DG (ed) Practical statistics for medical research. Chapman \& Hall, London, p 396-439

Anonymus (1990) LENKA, landsomfattende egnethetsvurdering av den Norske kystsonen og vassdragene for akvakultur Nor Off Utredn (NOU), 22, Oslo, p 144 (in Norwegran)

Bakken G (1995) The animal health and disease control situation in Norway 1995. Royal Ministry of Agriculture Department of Food Production and Plant and Animal Health, Oslo

Dannevig BH, Falk K, Namork E (1995) Isolation of the causal virus of infectious salmon anaema in a long-term cell line from Atlantic salmon head kidney. J Gen Virol 76: $1353-1359$

Dannevig BH, Falk K, Skjerve E (1994) Infectivity of internal tissues of Atlantic salmon, Salmo salar L., experimentally infected with the aetiological agent of infectious salmon anaemia (ISA). J Fish Dis 17:613-622

Dean AG, Dean JA, Burton AH, Dicker RC (1990) Epi Info Version 5: a word processing database and statistica] program for epidemiology on microcomputers. USD. Inc., Stone Mountain, Georgia, USA

Jarp J, Gjevre AG, Olsen AB, Bruheim T (1995) Risk factors associated with furunculosis, infectious pancreatic necrosis, and mortality in post-smolt of Atlantic salmon, Salmo salar L. J Fish Dis 18:67-78

Jarp J, Tangen K, Willumsen FW, Djupvik HO, Tveit AM (1993) Risk factors for infection with Aeromonas salmonicida subsp. salmonicida in Norwegian freshwater hatcheries. Dis Aquat Org 81:81-86

Pritchard DG, Allsup TN, Pennycott TW, Palmer NMA, Woolley JC, Richards MS (1989) Analysis of risk factors for infection of cattle herds with Leptospira interrogans serovar hardjo. In: Rowlands GJ (ed) Proceedings from the annual meeting of the Society for Veterinary Epidemiology and Preventive Medicine. Society for Veterinary Epidemiology and Preventive Medicine, Exeter, p 138-147

Schlesselman JJ (1982) Case-control studies. Oxford University Press, New York

Thomsen BL, Jorsal SE, Andersen S, Willeberg P (1992) The Cox regression model applied to risk factor analysis of infections in the breeding and multiplying herds in the Danish SPF system. Prev Vet Med 12:287-297 
Thorud KE (1991) Infectious salmon anemia. Thesis Dr Scientiarum, Norwegian College of Veterinary Medicine, Oslo Torgersen Y, Falk K, Dannevig BH., Hektoen $\mathrm{H}$, Krogsrud J (1993) Physical and chemical inactivation of the etiological agent of infectious salmon anemia (ISA). A qualitative study. European Association of Fish Pathologists, Sixth International Conference, September 5-10, 1993. Brest, Abstracts, p 5

Responsible Subject Editor: F M. Hetrick, College Park, Naryland, USA
Torgersen $Y$, Håstein T (1995) Disinfection in aquaculture. Rev Sci Tech Off Int Epizoot 14:419-434

Văgsholm I, Djupvik HO, Willumsen FV, Tveit AM, Tangen K (1994) Infectious salmon anaemia (ISA) epıdem.logy in Norway. Prev Vet Med 19:277-290

Webster AJF, Saville C, Church BM, Gnanasakthy A, Moss R (1985) Some effects of different rearing systems on health, cleanliness and injury in calves. Br Vet J 141:472-483

Manuscript first received: March 5, 1996 Revised version accepted: October 18, 1996 